\title{
Toward a Learning-centered EAP Instruction: An Attempt to Change Students' Reading Attitude
}

\author{
Seyyed Hossein Kashef (corresponding author) \\ School of Languages, Literacies, and Translation, Universiti Sains Malaysia, Penang, Malaysia \\ Ambigapathy Pandian \\ School of Languages, Literacies, and Translation, Universiti Sains Malaysia, Penang, Malaysia \\ Sima Modir Khameneh \\ English Department, Faculty of Humanities, Urmia University, West Azerbaijan, Urmia, Iran
}

\begin{abstract}
There have been remarkable improvements and modifications in TESOL methodology with the advent of post-method era; however, such changes are rarely implemented in fields like ESP. Therefore, a majority of learners and teachers are not satisfied with currently offered EAP courses. Hence, the present study aims at exploring the effect of a Learner-Centered Instruction on undergraduate students' reading attitude in an EAP context. Based on a pedagogical framework driven from Hutchinson and Waters' Learning-Centered ESP approach, it was assumed that such an approach would be effective in changing students' attitudes towards EAP reading through encouraging the use of effective strategies and learning skills. The participants aged 18 to 22 , included 80 engineering students who were divided into an experimental group and a control group. Following a pretest, treatment and a posttest, the obtained data was analyzed using $t$-test to examine the effect of the independent variable, namely, method of instruction. The findings revealed that learning-centered EAP instruction improves reading attitude of EAP students. In addition, the findings provide implications for all EAP practitioners in general and Asian EAP practitioners in particular.
\end{abstract}

Index Terms - learning-centered instruction, EAP, reading attitude, reading comprehension, undergraduate EAP students

\section{INTRODUCTION}

English for Academic Purposes (EAP), developed as a category of English for Specific Purposes (ESP), aiming to concentrate more on curriculum and instruction in tertiary education rather than focusing on analysis and theory (Hyland, 2006). Similarly, as stated by Hutchinson and Waters (1987), the focus of ESP is mainly on teaching language in context in contrast to grammatical and structural instruction of language. Thus, an EAP course brings about an appropriate context whereby the students' needs and functions of language are the cornerstones of instruction. Despite the fact that equal importance is given to all four language skills in a general English class, the objective of an EAP course can be a specific skill required by the students for a particular purpose such as their reading skills and its development in order to comprehend the technical texts of their specialty areas (Hutchinson \& Waters, 1987).

Similar to many EAP contexts in which English is considered as a foreign language, EAP is part of EFL instruction in Iran having a significant status in the tertiary education and all undergraduate students majoring in any fields of studies are required to pass EAP as a compulsory course subject (Moslemi, Moinzadeh, \& Dabaghi, 2011). Undoubtedly, the most required EAP skill in students 'tertiary education has been reading comprehension (Jordan, 1997). Similarly, the main goal of EAP courses in Iran is defined as developing reading comprehension of students to read academic texts in their related fields of studies (Hayati, 2008; Erfani, Iranmhehr, \& Davari, 2011; Farhady, Sajadi Hezhaveh, \& Hedayati, 2010). In spite of the fact that huge educational and financial investments have been made on EAP programs, the majority of students and teachers are not satisfied with these so-called EAP classes (Eslami, 2010). As a main reason bringing about the general dissatisfaction with EAP courses, teaching methodology has an important role. Although the post-method era has led to significant improvements and modifications in TESOL methodology, such changes are seldom applied in fields like EAP. As a result, using the existing well-developed literature on TESOL methodology, EAP practitioners need to take this opportunity to implement effective teaching approaches to compensate for students' shortcomings in a specific area. However, according to Hayati (2008), since EAP classes are out of skillful and creative teachers who can employ communicative approaches in the classroom, the main methodology in EAP context is still traditional Grammar-Translation Method (GTM). It is practiced in teacher-centered classes tough being very outdated and inefficient in developing reading comprehension ability of students which in turn leads to the dissatisfaction of both learners and teachers with these EAP courses and students' negative ideas toward English reading (Hayati, 2008; Mazdayasna \& Tahririan 2008; Ajideh, 2009; Farhadi et al., 2010; Erfani et al., 2011; Atai, 2011). 
Therefore, it was hoped that a learning-centered EAP instruction which considers the learners' needs and learning process and takes into account the appropriate skills and techniques necessary for this purpose can help the learners accomplish their goals. To this end, adopting Hutchinson and Waters' (1987) learning-centered approach as an innovative approach into EAP class in tertiary education context of Iran, the present study aimed to investigate if such an approach has any effect on students' attitudes towards academic reading since many students are reluctant to attend EAP classes due to the inefficiency of these courses in improving reading comprehension of students as claimed by Hayati (2008), Ajideh (2009), Atai (2011).

\section{LITERATURE REVIEW}

There has been a considerable amount of research on learners' reading attitude; however, few studies have been conducted concerning the reading attitudes of EAP students with an emphasis on methodology in different EAP contexts. Thus, in order to provide a clear background on the research carried out in this realm, some recent and relevant studies need to be reviewed.

In a theoretical article concerning EAP methodology, Watson Todd (2003) emphasized the remarkable role of methodology in EAP asserting that much of the work carried out on EAP has concentrated more on teaching content than methodology and many EAP practitioners have mainly focused on the course content neglecting the role of methodology in EAP course design. Through investigating EAP teaching reports, the article provided six types of approaches to EAP instruction, namely inductive learning, learner autonomy, process syllabus, authenticity, technology, and team teaching. He mentioned some reasons to support the importance of methodology in EAP. As the first reason, Watson Todd (2003) highlighted the main objective of EAP instruction which is enabling students to effectively communicate in academic contexts. Therefore, regardless of the content to be covered, the process of reaching that objective receives a significant role. A second reason to emphasize EAP methodology is that wherever EAP teaching method has been taken into account, it has been quite innovative with some implications for general English teaching. As a third reason, he claimed that despite the differences between EAP and general English teaching in content, the idea that they also differ in methodology has not been clarified yet. Finally, Todd Watson (2003) maintained the contribution of focusing on the how of EAP instruction to EAP teacher training stating that unlike the existence of experienced teachers in core countries, many EAP teachers in periphery countries are novice teachers which need to be trained on how to teach EAP. In addition to these reasons, the nature of students in EAP context as being more mature, selfdirected, and more aware has been mentioned as another factor characterizing EAP instruction.

In another study conducted with regard to ESP instruction in relation to the development of learners' different skills, Huang (2006) examined the ways that may motivate non-English major students to engage in EAP reading texts in an EFL context. He constructed a questionnaire including 18 statements describing various situations in which the students were motivated to read. The data was collected from 212 students of business in five randomly selected classes of a university of science and technology in Taiwan. Descriptive statistics showed that learners were most willing to read under three circumstances: when (1) teachers were available to answer the questions, (2) key points were highlighted clearly in textbooks, and (3) reading skills were taught (Huang, 2006). One can, therefore, infer from Huang's suggestion that teaching reading skills is one of the crucial factors that may motivate students to read efficiently. This, in turn, highlights the importance of teaching reading skills in an ESP and EAP program.

In EFL and EAP context of Iran as well, some related theoretical and empirical research studies have been carried out, among which some relevant ones are reviewed in the following.

Hayati (2008) has conducted a theoretical research study on ESP teaching challenges in Iran through which he sheds light on some common problems of ESP programs and gives some practical suggestions to improve their quality. In his study, he has asserted that although academic requirement of university students to pass ESP courses has dramatically increased, there is not enough literature on practical issues of these types of classes. He initiated his article elaborating on ESP branches and characteristics and moved forward to review different approaches of ESP. Then, he introduced Participatory Appraisal approach proposed by Holme and Chalauisaeng (2006) as a learner-centered approach that attempts to generate a positive attitude among learners to language learning and assist learners in attaining more selfdirection to develop their reading comprehension. Having argued some general notions about ESP, he shifted to highlight the issues of Iranian ESP context. Hayati (2008) declared that not only ESP programs have not been well criticized and assessed, but also they have not received adequate attention from the experts in the field. He pointed out the dissatisfaction of many students and teachers with ESP classes and provided some reasons for this event. It is stated that among accepted objectives of ESP courses in Iran, reading to understand test items and poor translation skill to do the assignments are more dominant. The classes are teacher-centered in which teachers translate the texts into Persian and students write down the meanings and grammatical structures are only described occasionally. He resembled ESP classes in Iran to samples of Grammar-Translation Method (GTM) and criticized the ignorance of learner's role and autonomy in these classes. Finally, Hayati (2008) reported some observations on ESP classes and highlighted the lack of knowledgeable teachers and appropriate methodology as one of the key factors leading to the inefficiency of ESP programs.

In much the same vein, Kiani (2010) also aimed to explain the current problems of English Language learning and attitudes toward English in Iranian EAP context. She began her discussion by reviewing the historical overview of the 
status of English language learning and teaching in Iran over the last 160 years. Then, coming to the present time, she pointed out the remarkable role of EAP courses as part of the curriculum for different academic disciplines in Iranian universities context. She highlighted that in spite of the great financial investment on English teaching in Iranian tertiary education, yet students cannot get satisfactory results in national and international proficiency tests which ,in effect, bring about both learners and teachers dissatisfaction of EAP courses. Kiani (2010) also mentioned that although there has been a systematic effort to create uniform EAP programs and discipline specific textbooks by the Center for Research and Development of Texts for University Students, well-known as SAMT in Iran, researchers criticized these textbooks for lacking communicative component and encouraging students to promote their reading skill merely through translation and grammatical skills (Farhdy and Hedayati, 2009). In addition, experts disapproved this approach, stating that it is unable to equip students with appropriate skills and strategies to succeed in their language learning objectives (Borjian, 2009). The important role of attitude in influencing learners' motivation to learn is also highlighted in this article supporting the idea that attitude is a major factor leading to failure or success in language learning (Gardner, 2007).

These studies have mainly focused on the theoretical aspects of EAP instruction There is a dearth of experimental studies and empirical evidence on the effects of innovative EAP instructions on undergraduate students' attitudes toward EAP reading. Thus, the current study was conducted to contribute to the learning-centered EAP instruction approach by filling in the gap on possible impacts of such methodology on improving the current status of EAP courses in Iranian university context.

\section{METHOD}

This research study adopted a quasi-experimental pre-test post-test control group design conducted to examine if a learning-centered instruction has any significant effect on students' attitudes towards EAP reading. To do so, two EAP classes were chosen and randomly assigned to be either a control group or an experimental group.

\section{A. Participants}

Eighty freshmen undergraduate students of engineering were selected from Urmia University of Technology in Iran forming two intact EAP classes. They were chosen by means of a background information questionnaire and a pre-test of English reading attitude. Homogeneity was established among the participants in terms of their age range (18-22), English Background, and university entrance exam English score.

\section{B. Instruments}

As far as research on reading comprehension is concerned, the key factors to consider include motivation, attitudes, age, language proficiency, English language experience and background knowledge (Alderson, 2000). It is believed that a rigorous control of these variables in the language learning contexts should be applied to get more generalizable findings as much as possible. Accordingly, a background information questionnaire adapted from Mackay and Gass (2005) was employed to select homogeneous participants and control as many intervening variables as possible.

Furthermore, a self-report Likert scale items questionnaire, adopted from $\mathrm{Wu}$ (2001), was utilized both in the pre-test and post-test stages to examine the possible change in students' attitudes toward academic English reading after implementation of the treatment. This questionnaire was utilized because it has been implemented in a similar context. It included 10 items with five scales from strongly agree to strongly disagree asking about students' ideas on reading in English. It was given to the students at the beginning of the study as a pre-test and at the end of the study as a post-test. To ensure the appropriateness of the questionnaire, its reliability and validity was measured prior to the study. The reliability result of the questionnaire using Cronbach's alpha formula revealed that it was in an acceptable range $(\mathrm{r}=0.76)$. In addition, the content validity of the questionnaire was also checked and confirmed by three experts in the field.

As the teaching material for the course, the book 'Select Readings' $2^{\text {nd }}$ Edition written by Linda Lee, Erik Gundersen, and Jean Bernard (2011) and published by OUP was used. This four-level American English reading course uses carefully selected and high interest reading texts to empower students read effectively. It contains a range of exercises before and after reading aiming at developing reading skills, examining comprehension and improving vocabulary knowledge. Thus, it was assumed that it can fulfill the purpose of this study.

\section{Procedure}

The experiment and data collection began at the outset of academic semester. The two selected EAP classes were held two sessions (approximately 90 minutes) a week. The experimental class was taught through a learning-centered approach while the control group only received the traditional reading method (GTM). All the data was collected during an academic semester in almost 4 months. In the beginning, the background questionnaire was given to the learners to ensure the homogeneity of the participants and control the intervening variables as much as possible. In addition, reading attitude questionnaire was administered as the pre-test in order to compare any change in their attitudes before and after the treatment. Then, the treatment was implemented. After following 22 sessions of instruction, post-test was administered to check for any significant difference between the two groups in terms of their EAP reading attitudes. 
The experimental class was taught through learning-centered method of EAP instruction proposed by Hutchinson and Waters (1987), considering learners' needs, interests, existing and required learning skills to reach the desired target defined as successful reading comprehension in the curriculum. In order to provide learners with certain reading strategies required during reading comprehension, reading strategies were also instructed as effective tools to improve students' reading comprehension. The teacher devoted the first sessions of the class to introducing and teaching the reading strategies. Then, he tried to point out the important role of these strategies and skills in dealing with different types of academic English texts. Finally, he modeled a number of reading strategies, including skimming and scanning, summarizing, note taking, inferencing, organizing, guessing meaning, using clues, and identifying text organization and guided the students to utilize them in 22 sessions respectively. Simultaneously, the teacher considered learners' interest and emotions during the instruction as the principles of learning-centered approach. He tried to keep the students' interest in the course developing positive emotions in the classroom and avoiding negative emotions as much as possible through some techniques such as applying pair work and group work, giving students' time to think, emphasizing more on process rather than product and respecting attitude the same as ability. In addition, following the principles of learning-centered approach of ESP instruction as proposed by Hutchinson and Waters (1987) and Jordan's EAP (1997), the teacher took into account learners' existing knowledge and skills in the content area and first language reading since these learners had already a high proficiency in their native language, thus, their knowledge in their native language was utilized to make them improve in EAP reading comprehension.

Generally, the learning-centered approach disapproving teacher-centered approaches considered learner's role in all stages of learning and teaching as an important factor in determining learning process.

\section{FINDINGS}

Initially, descriptive statistics was performed to organize both the experimental and control groups' data on reading attitudes. The data of the pre-test of the sample were described in order to make sure whether the two groups were homogeneous prior to carrying out the main study. Yet, as far as the post-test scores are concerned, descriptive statistics as well as inferential statistics were conducted on the two groups. The descriptive statistics displayed that the participants who received the treatment in the experimental group including 40 students had a range of scores between 29 and 55 with a mean of 40.92 and a standard deviation of 5.11 in the post-test.

On the other hand, the descriptive statistics for the control group demonstrated that the participants in this group consisting of 40 students had a range of scores between 23 and 49 with a mean of 38.20 and a standard deviation of 5.98 in the post-test.

Table 1 displays the descriptive statistics' results for the pre-test and post-test reading attitude administered to both the experimental and control groups before and after the treatment.

TABLE I.
DESCRIPTIVE STATISTICS OF THE READING ATTITUDE SCORES

\begin{tabular}{|l|l|l|l|l|l|l|}
\hline Group & Test & N & Min & Max & Mean & SD \\
\hline \multirow{2}{*}{ Experimental } & Pre-test & 40 & 24 & 50 & 38.25 & 5.64 \\
\cline { 2 - 8 } & Post-test & 40 & 29 & 55 & 40.92 & 5.11 \\
\hline \multirow{2}{*}{ Control } & Pre-test & 40 & 27 & 49 & 39.02 & 5.92 \\
\cline { 2 - 8 } & Post-test & 40 & 23 & 49 & 38.20 & 5.98 \\
\hline
\end{tabular}

As it can be observed in Table 1, the two groups had almost similar scores on their attitudes toward reading in the pre-test. However, according to the post-test scores, the two groups had different attitudes toward reading. The change in the mean scores of each group from the pre-test to the post-test is depicted in Figure 1.

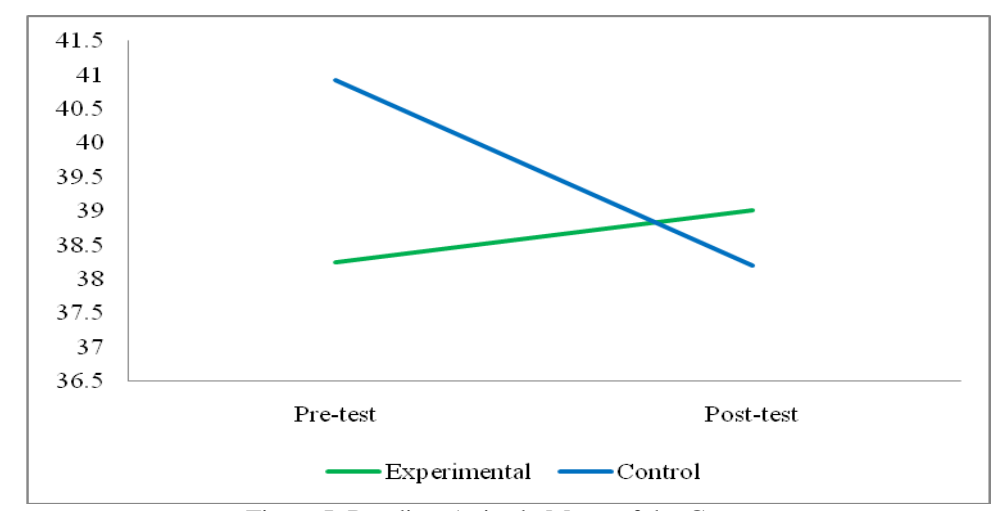

Figure I. Reading Attitude Mean of the Groups

Notably, based on the descriptive analysis of reading attitude questionnaire, the difference in the mean scores between the experimental and control group in the pre-test is almost small; however, this difference is a bit more in the 
post-test and needs to be examined whether it is significant or not. As a result, to determine the significance of this difference, inferential statistical analysis was conducted.

In order to analyze the significance of the mean difference and to test the proposed assumption, $t$-test was used to measure the possible effect of the method on the student's academic English reading attitudes. The independent-samples t-test was employed to compare the means scores of the experimental group with that of the control group and the paired-samples t-test was further conducted to compare the pre-test and post-test scores within each group in an attempt to assess if any change had taken place in students' reading attitudes at the end of instruction. The results of t-test revealed that the teaching intervention had a significant effect $(\mathrm{T}=2.18, \mathrm{P} \leq .05)$ on students reading attitude (Table 2). This means that the instruction was quite successful in improving students' EAP reading attitude.

TABLE II.

THE RESULTS OF INDEPENDENT-SAMPLES T TEST FOR READING ATTITUDE
\begin{tabular}{|l|l|l|l|l|}
\hline Group & Mean & df & $\boldsymbol{t}$ & $\boldsymbol{p}$ \\
\hline Experimental & 40.92 & 78 & 2.18 & .03 \\
\hline Control & 38.20 & 78 & & \\
\hline
\end{tabular}

However, the within-group comparison conducted through paired samples t-test (Table 3) measuring the impact of the intervention on the students' scores, indicated a significant increase in the reading attitude scores of the experimental group from the pre-test $(\mathrm{M}=38.25, \mathrm{SD}=4.10)$ to the post-test $(\mathrm{M}=40.92, \mathrm{SD}=5.11, \mathrm{t}(39)=-4.25, p=.00)$.

Furthermore, another paired-samples t-test was conducted on the control group to check any significant change in the reading attitude scores of this group at two different times in an attempt to make sure whether the change in the experimental group's scores was occurred by the influence of the independent variable, namely, learning-centered EAP instruction. The results of this analysis not only displayed no significant improvement in the reading attitude scores of the control group before $(\mathrm{M}=39.02, \mathrm{SD}=5.92)$ and after the course $(\mathrm{M}=38.20, \mathrm{SD}=5.98, \mathrm{t}(39)=1.02, p=.31)$, but it demonstrated a minor fall in the attitude scores of the control group though this reduction was not significant.

Thus, it can be inferred that the experimental group had a considerable positive change in their reading attitudes due to receiving the learning-centered EAP instruction. On the other hand, it is implied that the control group almost developed a negative attitude after being taught with the common traditional method for a semester, although this change was not statistically significant. Table 3 depicts the results of the paired-samples t-test for the two groups.

TABLE III.

PAIRED-SAMPLES T TEST FOR THE READING ATTITUDE SCORES

\begin{tabular}{|c|c|c|c|c|c|c|c|}
\hline Group & Time & $\mathbf{N}$ & Mean & SD & $t$ & df & $p$ \\
\hline \multirow{2}{*}{ Experimental } & Pre-test & \multirow{2}{*}{40} & 38.25 & 4.10 & \multirow{2}{*}{-4.25} & \multirow{2}{*}{39} & \multirow{2}{*}{.00} \\
\hline & Post-test & & 40.92 & 5.11 & & & \\
\hline \multirow{2}{*}{ Control } & Pre-test & \multirow{2}{*}{40} & 39.02 & 5.92 & \multirow{2}{*}{1.02} & \multirow{2}{*}{39} & \multirow{2}{*}{.31} \\
\hline & Post-test & & 38.20 & 5.98 & & & \\
\hline
\end{tabular}

In order to examine the effect size of the independent variable on the dependent variable; namely, reading attitude, the effect size statistic was conducted. According to Pallant (2005), effect size is a statistic used to determine the degree of total variance in the dependent variable through knowing independent variable and the amount of the difference between the means which is usually measured by eta squared. Commonly, eta squared amounts can be divided into three effect sizes: .01 for small effect, .06 for average effect, and .14 for large effect given by Cohen (1988, cited in Pallant, 2005).

The effect size calculation using eta squared showed number .05 which is close to .06 indicating almost a moderate effect of the instruction on reading attitudes of the students. In other words, the eta squared showed that 6 percent of the variance in reading attitude is brought about by the experimental treatment. Moreover, a very large effect size $(\mathrm{d}=.31)$ was obtained from the paired-samples t-test results of the experimental group. Therefore, it can be implied that the learning-centered instruction explained a very large amount of variation in reading attitude scores of the students. In other words, the eta squared .31 demonstrated that 31 percent of the change and variation in the reading attitude as the dependent variable is explainable by the manipulation of the treatment, namely, learning-centered EAP instruction as the independent variable in the experimental group.

In short, Iranian undergraduate students who receive learning-centered EAP instruction show an improvement in their attitudes toward reading in contrast to their peers who receive conventional reading instruction. Additionally, the students who were taught through traditional reading instruction were likely to make any change in their reading attitudes possibly due to their lack of interest in the type of instruction and a gap in their knowledge of reading strategies.

\section{DISCUSSION AND CONCLUSION}

The findings of this study revealed that the type of instruction and teaching methodology plays an important role in shaping students' attitudes toward academic English reading. In other words, a learning-centered instruction which 
focuses on learners' learning process and needs can change students' negative attitudes toward EAP reading and compensate for their dissatisfaction with teacher-centered EAP classes.

This study aimed to draw teachers' attention to the importance of learning-centered approaches and the significance of methodology other than syllabus design and evaluation (Watson Todd, 2003) in EAP context. The present study adds to the previous body of research carried out on the role of innovative reading instruction in academic contexts. It encourages the implementation of a learning-centered approach in EAP reading courses as opposed to teacher-centered GTM classes. It approves the implementation of all crucial principles of Hutchinson and Waters' learning-centered approach which encourage the consideration of learner and his or her preferences and needs along the leaning process.

As an influential factor in reading instruction, students' attitudes toward reading and their interest in reading should not be neglected. This is in line with Hutchinson and waters (1987) and Jordan's (1997) learning-centered ESP and EAP approaches respectively drawing attention to the effect of learners' attitude and motivation in their learning process highlighting the role of positive emotions in the classroom and calling attention to respecting the attitude and the ability of learners through having fun, and variety in instruction.

The implication of these findings is that the Iranian students of EAP with seven years of experience in learning English at school starting from junior high school are not only unable to benefit from the language and linguistic knowledge they have learned during this period but also they cannot apply this knowledge in reading comprehension tasks. This is also in line with the extensive agreement among scholars (Riazi, 2005; Borjian, 2009; Farhady \& Hedayati, 2009; Farhady et al., 2010) claiming the inefficiency of English programs at Iranian schools which revolve around sort of teacher-centered grammar-translation method with passive students not prepared for performing communicative and functional tasks and becoming language users. The same problem exists and goes on in the universities where the type of materials designed and used for the English courses are mainly promoting vocabulary and grammar knowledge neglecting communicative aspect of language (Amirian \& Tavakkoli, 2009; Borjian, 2009; Farhady et al., 2010). Therefore, as also stated by Hayati (2008) and Kiani (2010) a negative attitude develops and dissatisfaction arises toward English reading and EAP classes as a result of their inefficiency in terms of developing communicative language skills of students and preparing them for successful reading comprehension in their EAP courses.

Furthermore, it can be concluded that a learning-centered instruction in EAP context, in contrast to the traditional teacher-centered grammar translation instruction, can be effective in helping students improve their reading comprehension and, this in turn, aids students develop a positive attitude toward EAP reading courses since they are satisfied with their achievement at the end of the course. In other words, the inefficiency of the methodologies and instruction in developing reading comprehension of the learners is the main reason leading to the dissatisfaction of students and even teachers with EAP courses as highlighted by Hayati (2008). Therefore, it can be concluded that, a learning-centered instruction is not only effective in enhancing reading comprehension of the students, but also it can change their ideas on the EAP course and the whole curriculum. The teacher-centered approach that is employed in teaching reading in English does not seem to encourage active participation on the part of the students. Therefore, the lack of learner autonomy in the class leads to a generally negative attitude toward English reading. The students usually find the class instruction as boring and machine-like feeling anxious about being able to answer the comprehension questions after the reading passages. In effect, the EAP students would develop negative self-concepts as passive readers of academic English texts. Teachers should not neglect their students' difficulties in reading academic English texts and attempt to motivate students to use their existing skills and background knowledge while involved in reading tasks (Kaur, 2013). Additionally, as stated by Musa, Koo and Azman (2012) as students reading comprehension improves and they become proficient readers, their motivation increases and, as a result, their interest is preserved and they start to have positive attitudes toward reading.

\section{REFERENCES}

[1] Ajideh, P. (2009). Autonomous learning and metacognitive strategies essentials in ESP class. English Language Teaching, 2 (1), 162-168.

[2] Alderson, J.C. (2000). Assessing reading. Cambridge: Cambridge University Press.

[3] Amirian, Z., \& Tavakoli, M. (2009). Reassessing the ESP courses offered to engineering students in Iran: a case study. English for Specific Purposes World, 8(23) 1-13. Retrieved January 1, 2012, from www.esp-world.info.

[4] Atai, M. R. \& Nazari, O. (2011). Exploring Reading Comprehension Needs of Iranian EAP Students of Health Information Management (Him): A Triangulated Approach." System 39, (1) 30-43.

[5] Borjian, M. (2009). English education in post-revolutionary Iran (1979-2008): The politics of educational borrowing and lending. Unpublished doctoral dissertation. Columbia University, United States of America.

[6] Erfani, S.M., Iranmehr, A. \& Davari, H. (2011). Deepening ESP Reading Comprehension through Visualization. Journal of Language Teaching and Research, 2, (1), 270-273.

[7] Eslami, Z. R. (2010). Teachers' voice vs. students' voice: A needs analysis approach to English for Academic Purposes (EAP) in Iran. English Language Teaching. 3 (1), 3-11.

[8] Farhady, H., \& Hedayati, H. (2009). Language assessment policy in Iran. Annual Review of Applied Linguistics, 29, $132-141$.

[9] Farhady, H., Sajadi Hezaveh, F., \& Hedayati, H. (2010). Reflections on foreign language education in Iran. TESL-EJ, 13 (4). Retrieved January 1, 2012, from http://www.tesl-ej.org.

[10] Gardner, R. C. (2007). Motivation and second language acquisition. Porta Linguarum 8, 9-20. 
[11] Hatch, E. \& Farhady, H. (2007). Research design and statistics ( $5^{\text {th }}$ ed.). Tehran: Rahnema Publications.

[12] Hayati, A.M. (2008). Teaching English for Special Purposes in Iran: Problems and suggestions. Arts and Humanities in Higher Education, 7, 149-165.

[13] Holme, R. \& Chalauisaeng, B. (2006) 'The learner as needs analyst: The use of participatory appraisal in the EAP reading classroom'. English for Specific Purposes 25(4), 403-419.

[14] Huang, S.-C. (2006). Reading English for Academic Purposes. What situational factors may motivate learners to read? System, 34(3), 371-383.

[15] Hutchinson, T., \& Waters, A. (1987). English for Specific Purposes. Cambridge: Cambridge University Press.

[16] Hyland, K. (2006). English for Academic Purposes: an Advanced Resource Book. Routledge Applied Linguistics.

[17] Jordan, R. R. (1997). English for Academic Purposes. Cambridge Books Online: Cambridge University Press.

[18] Kaur, S. (2013). Critical Literacy Practices of English Major in a Tertiary Institution. GEMA Online® Journal of Language Studies, 13(2), 21-39.

[19] Kiani, S. (2010). Attitudes toward English: The practice of teaching English for Academic Purposes (EAP) in Iranian universities. Journal of the Pacific Circle Consortium for Education, 22 (2), 77-88.

[20] Lee, L., Gundersen, E., \& Bernard, J. (2011). Select Readings (2nd ed.). Oxford: Oxford University Press.

[21] Mackay, A., Gass, S.M. (2005). Second language research: methodology and design. Lawrence Erlbaum Associates, Inc., Publishers.

[22] Mazdayasna, G., \& Tahririan, M. H. (2008). Developing a profile of the ESP needs of Iranian students: The case of students of nursing and midwifery. Journal of English for Academic Purposes, 7(4), 277-289.

[23] Moslemi, F., Moinzadeh, A., \& Dabaghi, A. (2011). ESP needs analysis of Iranian MA students: A case study of the University of Isfahan. English Language Teaching, 4 (4), 121-129.

[24] Musa, N. C., Koo, Y. L., \& Azman, H. (2012). Exploring English language learning and teaching in Malaysia. GEMA: Online Journal of Language Studies, 12(1), 35-51.

[25] Pallant, J. (2007). SPSS Survival Manual ( $3^{\text {rd }}$ ed.). A step by step guide to data analysis using SPSS for windows (Version 12) ( $2^{\text {nd }}$ ed.). Maidenhead, Berkshire: Open University Press.

[26] Riazi, A. (2005). The four language stages in the history of Iran. In Decolonization, globalization: Language-in-education policy and practice, ed. A.M.Y. Lin and P.W. Martin, 98-114. Clevedon, UK: Multilingual Matters.

[27] Watson Todd, R. (2003). EAP or TEAP? Journal of English for Academic Purposes, 2(2), 147-156.

[28] Wue, Chi-Cheng. (2001). The use of American children's literature with college level students in Taiwan and its effects on attitudes towards reading in English and progress in English. Unpublished Ed.D thesis, University of Northern Colorado, Greeley, Colorado.

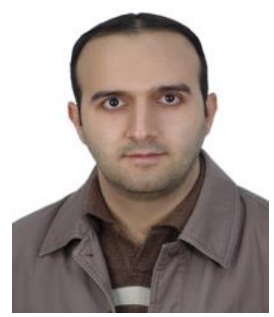

Seyyed Hossein Kashef is a PhD student in Applied Linguistics at the school of Languages, Literacies and Translation in Universiti Sains Malaysia. He has taught EFL classes for 4 years. As a university teacher, he has taught English and ESP courses for undergraduate students at Urmia University and Islamic Azad University of Urmia since 2009. He has published many research articles in his research interest areas including ESP/EAP, language learning strategies, teaching methodology and reading comprehension.

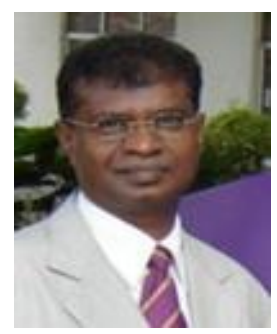

Ambigapathy Pandian is a Professor at the School of Languages, Literacies and Translation, Universiti Sains Malaysia. His research interests include language and literacy education, TESOL, sociolinguistics and more recently on higher education. He is very well published, being the author and editor of more than 30 books and many articles featured in local and International journals

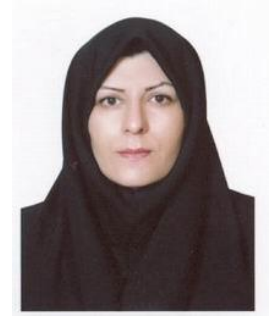

Sima Modir Khameneh is an Assistant Professor at English Department, Faculty of Humanities in Urmia University of Iran. She received her PhD degree in English Language Teaching from the University of Surrey. Currently, she is the head of the English Department. She has published many research papers in her research interests including bilingualism, language learning strategies, multiple intelligences. 